\title{
Smart Monitoring Agriculture Based on Internet of Things
}

\author{
$1^{\text {st }}$ Fachrul Kurniawan \\ PhD Candidate at Dept. of Electrical \\ Engineering, \\ Institut Teknologi Sepuluh Nopember \\ Surabaya, Indonesia \\ Dept. of Informatics Engineering, \\ Universitas Islam Negeri Maulana Malik \\ Ibrahim, \\ Malang, Indonesia. \\ fachrulk@ti.uin-malang.ac.id, \\ fachrulkurniawan873@gmail.com \\ $4^{\text {th }}$ Sri Harini \\ Faculty of Science and Technology, \\ Universitas Islam Negeri Maulana Malik \\ Ibrahim Malang, Indonesia \\ sriharini@mat.uin-malang.ac.id
}

\author{
$2^{\text {nd }}$ Hani Nurhayati \\ Dept. of Informatics Engineering,
iversitas Islam Negeri Maulana Malik \\ Dept. of Informatics Engineering,
Universitas Islam Negeri Maulana Malik \\ Ibrahim \\ Malang, Indonesia \\ hani.hayati@gmail.com \\ $5^{\text {th }}$ Supeno Sumardi Susiki Nugroho \\ Dept. of Electrical Engineering, \\ Institut Teknologi Sepuluh Nopember, \\ Surabaya, Indonesia \\ smardi88@gmail.com
}

\author{
$3^{\text {rd }}$ Yunifa Miftachul Arif \\ Dept. of Informatics Engineering, \\ Universitas Islam Negeri Maulana Malik \\ Ibrahim \\ Malang, Indonesia \\ yunif4@gmail.com
}

\author{
$6^{\text {th }}$ Mochamad Hariadi \\ Dept. of Electrical Engineering, \\ Institut Teknologi Sepuluh \\ Nopember, \\ Surabaya, Indonesia \\ mochar@gmail.com
}

\begin{abstract}
Agriculture is one of the issues that never runs out to be discussed. Since agriculture is one of the main sources of livelihood of the rural population. Therefore, the construction of agricultural data-based internet of things is very important to do. In this paper we present the steps of making agricultural monitoring tool-based internet of things in a comprehensive manner, using prototyping methods drawn from the experience of the agricultural process. A combination of hardware and software that uses data communication-based wireless fidelity (Wi-Fi) allow monitoring parameters of agricultural data visually and accurately, making it easier for farmers to act when something events that require rapid handling.
\end{abstract}

\section{Keywords- Agriculture; Internet of things; Data monitoring Introduction}

\section{INTRODUCTION}

The issue of agriculture is an important topic in particular in developing countries, this is because it will be influential in improving the quality of human resources and is also a means to maintain social and political stability as a prerequisite implement development[1][[2]. The farm is the source of food security which became a fundamental right for every human being which must be fulfilled for the sake of maintaining survival. Indonesia is a country which has a population of nearly the whole making of rice as a staple. Therefore, agriculture should be developed into a better and modern, especially in the use of technology so that increased crop yields become larger and significant [2][3].

Agriculture is one of the economic populist bases in Indonesia. Agriculture also became the determining resilience, even food sovereignty. However, in the majority of fertile land from agricultural livelihoods depend is still not able to improve the standard of living that is more prosperous [4][5]. The crisis of the failed harvest always haunts in agricultural areas in several rural areas of agricultural producers. So much is causing a growing rise in the price of agriculture in urban areas, it is swept up in the agricultural areas that are lacking in supplying his crop [2].

The use of technology is one of the conditions for making agriculture better because the data needed can be produced more so that the analysis will be better and more valid. The use of technology in agriculture has so far been limited to the tools used in processing the land or processing crops, and is still very limited in producing data on the cropping process until there is harvest [6][7]. According to the data obtained by the researchers, there are still many farmers who use traditional methods in analyzing the planting process so that the analysis is still the same as previous farming methods.

Technology internet of things (IoT) is a concept in which an object has the ability to transfer data over the network without requiring interaction human to human or human to computer, where data generated from the tools (sensors) attached to the selected object [2][6]. The ability of the sensor- sensor made in accordance with the purposes of the object that wants to be taken continuously data automatically and do not know the time. So that the data becomes large and can be used as the input so that the resulting analysis-analysis to create solutions [8]. One example of IoT implementation is a refrigerator that can notify its owner via short message service or e-mail about any food and drinks that have been used up and must be checked again. In agriculture, there are many things that can be done in implementing IoT, namely information about water, about fertilizer needs or about the development of plants that are growing[4][8][9]. In this paper will be presented about the process of making agricultural monitoring tool-based internet of things, which will also be 
elaborated about the design and also the equipment used both in the hardware and software.

\section{METHODOLOGY}

\section{A. Smart Monitoring Agriculture Design}

This is section explains the scheme about creating agricultural data monitoring tools by adopting prototyping processes, Fig. 1.

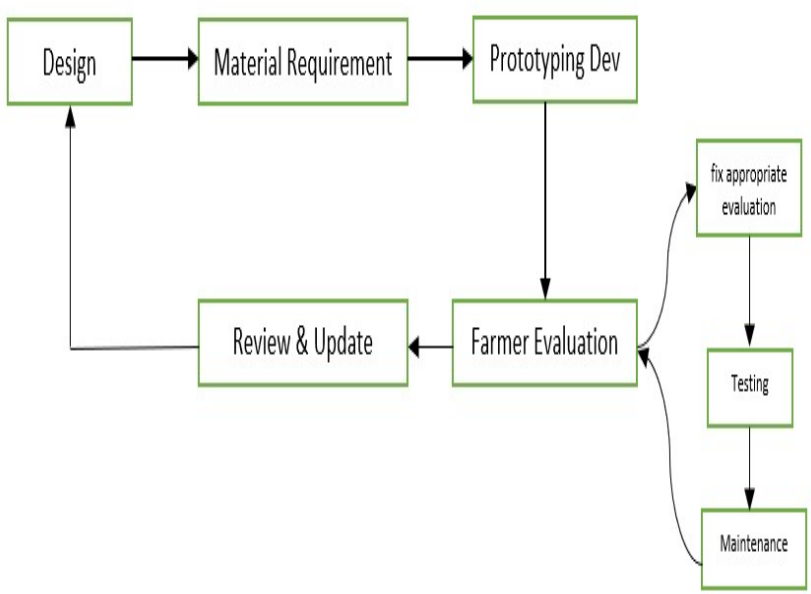

Fig. 1. Workflow Developing Smart Monitoring Agriculture

Steps of assembling were started initiated the scheme process managing two parameters, farming soil condition and energy use independently [10]. Furthermore, determine the material requirements in terms of hardware, software and data communication. After all, materials are available, a prototype is made according to the design and must be evaluated directly by the farmer so that if there is an evaluation the repair process will be carried out then a trial is carried out until then agreed by the farmer, that tool is in accordance with their needs[7][11].

To start creating device smart monitoring agriculturebased internet of things, it is necessary to make the communication process from the data flow so that the formed requirement tools that should be there. And here is the design of the smart flow monitoring agriculture.

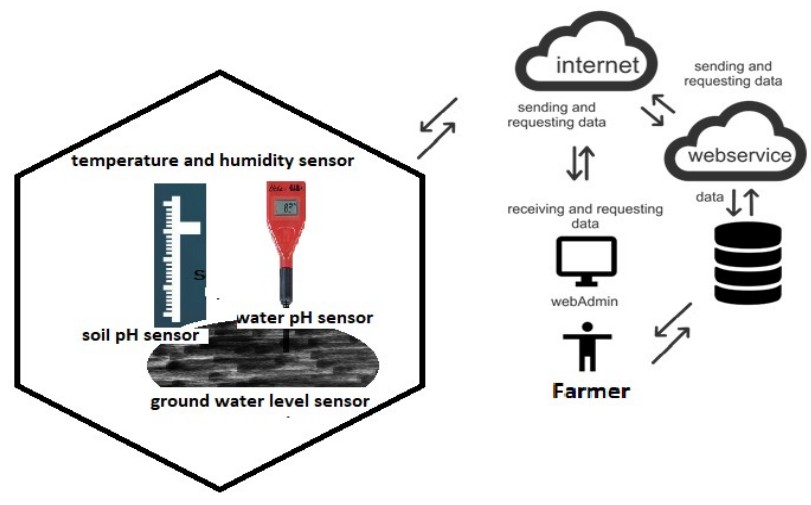

Fig. 2. Design of Smart Monitoring Agriculture

There are four sensors needed, namely a water $\mathrm{pH}$ sensor; temperature and humidity sensors; soil $\mathrm{pH}$ sensor; and groundwater level sensors, it will be assembled using
Arduino so that it can be connected to one another. This is to ensure the sensor will work properly, marked by the transmission of the four sensor detection data[12]. Realtime data can be directly seen by farmers and also stored on servers and cloud. Where the data in real time can be directly seen by farmers and also stored on servers and the cloud [9].

\section{B. Hardware and Network Requirement}

Hardware requirements in this study are divided into two, namely the hardware used to make internet of things (IoT) equipment and the devices used as support for communication and data storage circuits. Some of the main equipment are as follows; mini D1 wemos, $12 \mathrm{~V}$ fan, acrylic casing, Arduino and electronic components, water $\mathrm{pH}$ sensor; temperature and humidity sensors; soil $\mathrm{pH}$ sensor; and groundwater level sensors. In addition to support data communications hardware required for two-way communication that is attached to the $\mathrm{Wi}-\mathrm{Fi}$ device hardware IoT placed on fields and communication devices held by farmers.

\section{Algorithm Requirement}

The use of the software required to connect the main hardware with supporting hardware, and also to translate the receipt of data generated by the sensors into the device held by the farmer. In addition, this software is used to model data so as to produce recommendations for solutions needed by farmers. There are 2 software used, namely thinger.io (open source), PHP programming language and MATLAB. Management concerning software to synchronize IoT sensors so that they can read agricultural data according to the specified sensor range, pseudocode below;

1. Start

2. Connecting ThingerESP8266 thing;

3. username "iotpertanian"

4. Password "pd"

5. Read data;

6. Read dataIn;

7. Read dt [10];

8. Read i;

9. Read Serial 9600;

10. Read PHair

11. Read PHtanah

12. Read SoilMoisture

13. Read Suhu

14. IF Sensor $=4$

15. Print Data PHair

16. Print PHtanah

17. Print Soil Moisture

18. Print Suhu

19. End

\section{Energy Requirement}

Energy requirements are very important because this tool must work full 24 hours to be able to provide information to farmers about the development of rice fields according to the specified radius. So, this tool uses energy using solar panels so that the sensor device can transmit data in an update. And the following material used is SCC 20 A MPPT, Voltage step down MPPT 5A, solar cell 20wp, MC4 socket 
connector cable solar panel, NYYHY cable (solar panel cable). Design according to the following Fig. 5

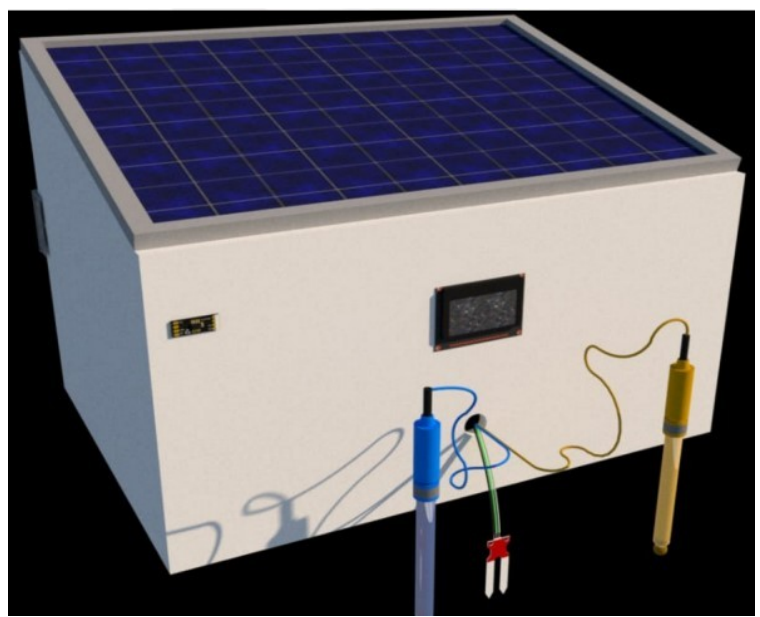

Fig. 3. Design of energy supply IoT agricultural

\section{RESULTS AND DISCUSSION}

In Figure 5, shows the smart monitoring agriculture design, which contains hardware and software. Farmers can immediately understand the layout of the tool so that it can easily operate. Besides that, farmers also understand how sensors work so they can read data sent to smartphones and server computers. This implementation produces two things, namely the frontend and backend sides.

\section{A. Frontend}

Devices located on farming areas and equipped with WiFi and electricity communication lines using solar cells are the frontend of this study. Equipped with four main sensors that record the condition of soil $\mathrm{pH}$, water $\mathrm{pH}$ and temperature and humidity in the farming area. Solar cell controller is done automatically so that at any time off immediately detected. Then also carried out automatic control of data communication connectivity so that the delivery of reports from sensors to smartphone farmers and servers smoothly.

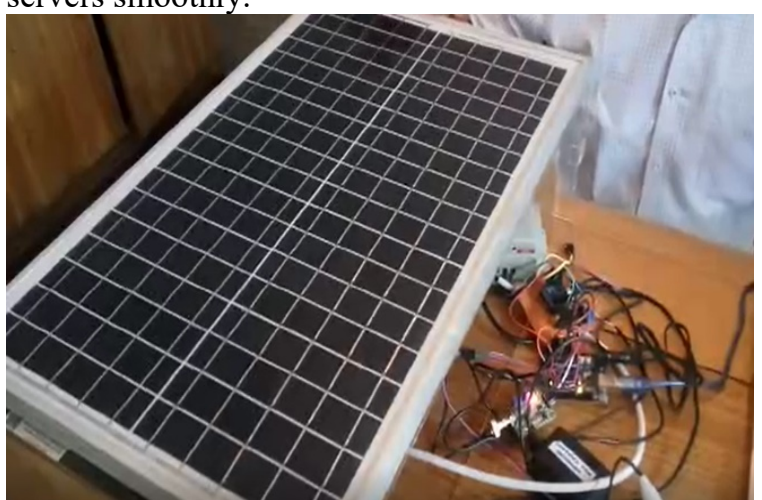

Figure 4. Frontend IoT smart monitoring agriculture

The series of tools in Figure 6 is a smart monitoring frontend that will be installed in the agricultural area. All indicators of installed devices have lights as a sign that all devices are working, and notifications sent to computer servers. The energy indicator will show a green light as a sign of current electricity supply and if the red light is not smooth, the energy supply will send a notification to the server computer. The sensor work detection lamp is given a blue color as a sensor detection indication there is no problem, and it is indicated that the notification of water, temperature and ground data to the computer server is smooth, but if the orange light indicates there is an unsettled sensor. For data communication, whether smooth or having problems, is marked with a network signal that is visible in small LCD screen as shown in Figure 7.

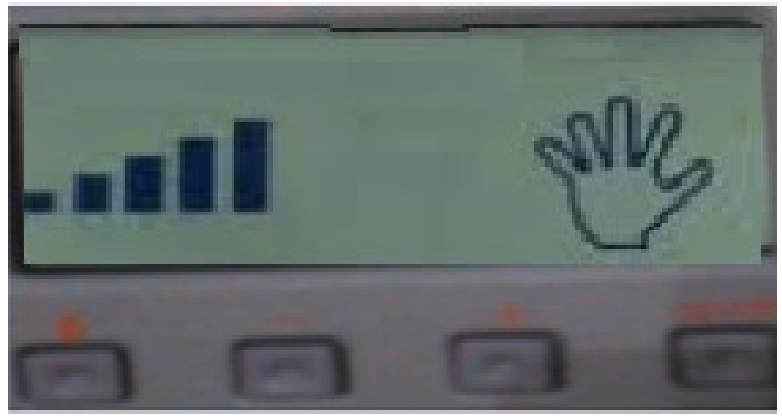

Figure 5. Network indicator

\section{B. Backend}

In addition to smart monitoring tools that must be placed in the rice field area, this research also produces applications installed on computer servers and smartphone farmers. This application displays all the indicators from the smart monitoring tool and data storage on a network server.

As a backend, web-based applications have four main menus, namely; statistics, dashboards, devices, and data bucket. The statistics menu describes the conditions of all menus displayed in graphical form. Describe the position of the detected device shown through the map, and finally shows the connectivity of receiving the installed sensor signal, as shown in figure 8.

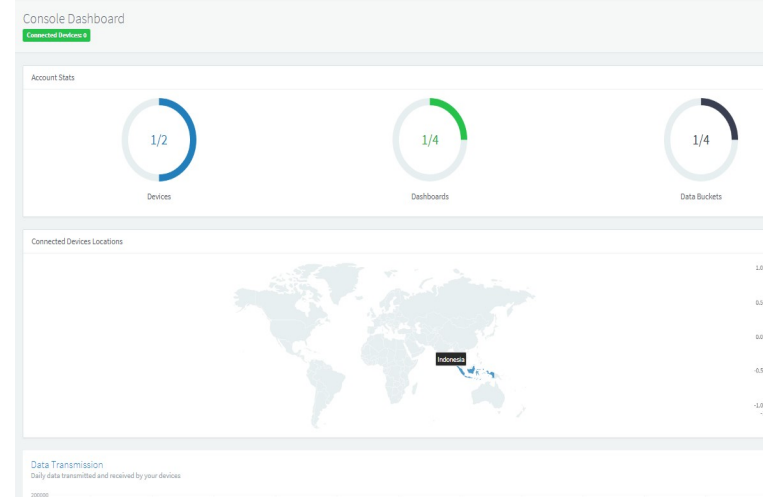

Figure 6. Statistics Menu

The dashboard menu functions as the recipient of the data sent from the agriculture smart monitoring tool that is placed in the agricultural area. The data display will be seen as two values and graphs (figure 9). Furthermore, the device menu displays a list of devices installed and detected to work properly. Shown as shown in Figure 10, detection of equipment can be seen directly where the data moves according to the settings desired by the user. 


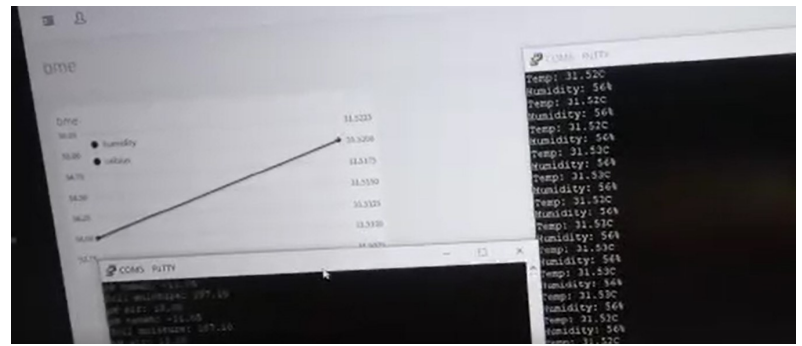

Figure 7. Dashboard menu

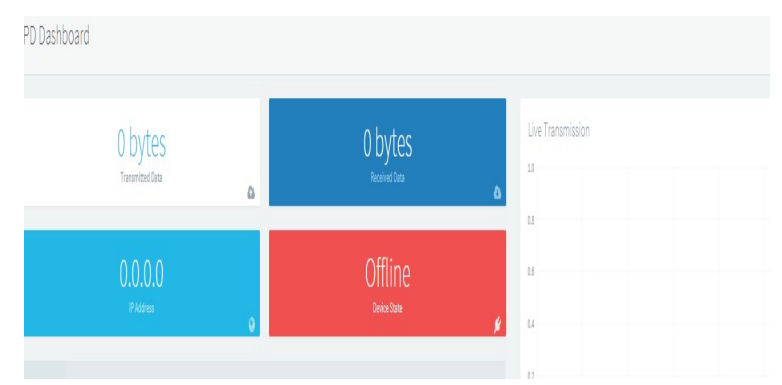

Figure 8. Device menu

In the data bucket menu serves as a storage place, indicated by the display of data recordings of each recorded device. In this menu, you can also export recorded data in accordance with the user's wishes for the data type, as shown in Figure 11 below.

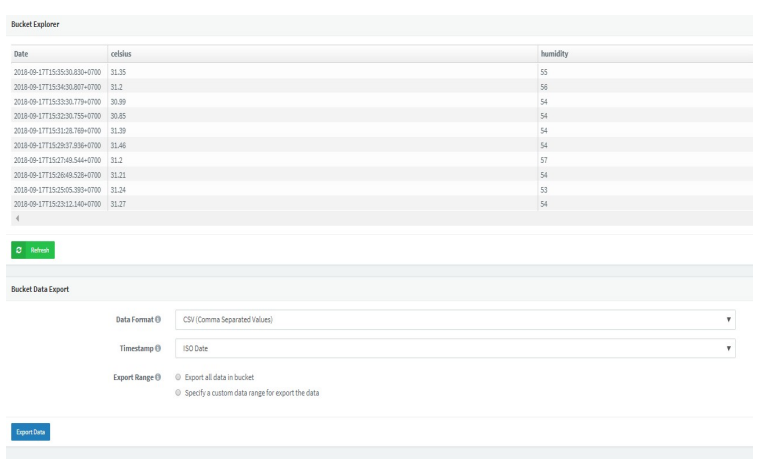

Figure 9. Data bucket menu

All devices installed in smart monitoring agriculture can perform according to the scheme. Trials will continue to be carried out in various weather conditions so that physical equipment will be seen. Evaluation will continue to be carried out to become a record for researchers in making improvements and development in the future. In the future the researcher will focus on the data modelling that has been obtained by smart monitoring agriculture, it is expected that a recommendation model for each area of agriculture will be produced.

\section{CONCLUSION}

We have presented the design, workflow, and implementation of smart monitoring agriculture-based internet of things. We focus discusses the implementation of making smart monitoring agriculture to identify farming data in real time. This identification is one of the solutions provided by researchers to help farmers in Indonesia resolve some issues that often occur. Because of the identification of agricultural data very much, but we're still focusing on the four sensors only. The first stage of the Smart Monitoring Agriculture based on IoT will be completed and continue to undergo trials in various weather conditions to obtain data on the durability of the installed equipment. Next, researchers will conduct trials of agricultural data using algorithms recommendations.

\section{AKNOWLEDGMENTS}

The authors thank specially to members of the research team that can finish on time. This research was supported by a grant from Applied Research and National Development from the Directorate General of The Islamic Higher Education of the Ministry of Religion of the Republic of Indonesia Number 3212 / Un.3 / HK.00.5 / 05/2018.

\section{REFERENCES}

[1] A. Kaloxylos et al., "The Use of Future Internet Technologies in the Agriculture and Food Sectors: Integrating the Supply Chain," Procedia Technol., vol. 8, no. Haicta, pp. 51-60, 2013.

[2] R. Nikkilä, I. Seilonen, and K. Koskinen, "Software architecture for farm management information systems in precision agriculture," Comput. Electron. Agric., vol. 70, no. 2, pp. 328-336, 2010.

[3] M. Prabhavathi and A. Kiranmai, "Smart Security for agriculture using IoT," Int. J. Adv. Eng. Res. Sci. Spec. Issue-4, vol. 6495, no. 4, pp. 2456-1908, 2017.

[4] C. Future and F. Tichakunda, "Challenges and Prospects of Zimbabwe's Command Farming in Unlocking the Country' s Smallholder Agricultural Economy," vol. 3, no. 4, pp. 76-82, 2018.

[5] F. Kurniawan, A. P. Wibawa, Munir, S. M. S. Nugroho, and M. Hariadi, "Makassar smart city operation center priority optimization using fuzzy multi-criteria decision-making," Int. Conf. Electr. Eng. Comput. Sci. Informatics, vol. 4, no. September, pp. 289-293, 2017.

[6] F. TongKe, "Smart Agriculture Based on Cloud Computing and IOT," J. Converg. Inf. Technol., vol. 8, no. 2, pp. 210-216, 2013.

[7] H. Kausarian, J. Tetuko, S. Sumantyo, D. Bagus, and E. Putra, "Image processing of alos palsar satellite data, small unmanned aerial vehicle ( UAV ), and field measurement of land deformation," vol. 4, no. 2, pp. 132-141, 2018.

[8] M. Farooq, M. Waseem, A. Khairi, and S. Mazhar, "A Critical Analysis on the Security Concerns of Internet of Things ( IoT )," Int. J. Comput. Appl., vol. 111, no. 7, pp. 1-6, 2015.

[9] G. P. -, S. Y. -, C. J. -, D. M. -, and L. B. -, "Enterprise-oriented Communication among Multiple ESBs based on WSNotification and Cloud Queue Model," Int. J. Adv. Comput. Technol., vol. 3, no. 7, pp. 255-263, 2011.

[10] J. Xiao and R. Boutaba, "The design and implementation of an energy-smart home in Korea," J. Comput. Sci. Eng., vol. 7, no. 3, pp. 204-210, 2013. 
[11] X. Ma, C. Lin, H. Zhang, and J. Liu, "Energy-aware computation offloading of IoT sensors in cloudletbased mobile edge computing," Sensors (Switzerland), vol. 18, no. 6, pp. 1-12, 2018.

[12] H. Atlam, R. Walters, and G. Wills, "Fog Computing and the Internet of Things: A Review," Big Data Cogn. Comput., vol. 2, no. 2, p. 10, 2018. 